\title{
Study the analgesic effect of diclofenac and silymarin coadministration in chicks
}

\author{
Y.M. Albadrany ${ }^{\circledR}$, A.S. Naser ${ }^{\circledR}$ and M.M. Hasan
}

Department of Physiology, Biochemistry and Pharmacology, College of Veterinary Medicine, University of Mosul, Mosul, Iraq

\section{Article information}

Article history:

Received May 07, 2020

Accepted May 22, 2020

Available online December 7, 2021

\section{Keywords:}

Diclofenac

Silymarin

Analgesia

Isobolographic analysis

Chicks

Correspondence:

Y.M. Albadrany

yasseralbadrany@yahoo.com

\begin{abstract}
The study aimed to investigate the analgesic as well as anti-inflammatory effects of diclofenac and silymarin in chicks. The up and down procedure was used to assess the effective median analgesic dosages $\left(\mathrm{ED}_{50 \mathrm{~s}}\right)$ of diclofenac and silymarin administered intraperitoneally either alone or at the same time in chicks. Also, Analgesic and antiinflammatory effects were measured by using the formalin test. Isobolographically, $\mathrm{ED}_{50 \mathrm{~s}}$ of drugs were assessed for the manner of interaction between both. Formalin testing also supervised analgesic and anti-inflammatory coadministration impact of diclofenac and silymarin at doses 5 and $40 \mathrm{mg} / \mathrm{kg}$ and 2.5 and $20 \mathrm{mg} / \mathrm{kg}$ respectively. Analgesic $\mathrm{ED}_{50 \mathrm{~s}}$ for diclofenac and silymarin in chicks were 9.3 and $76.6 \mathrm{mg} / \mathrm{kg}$ separately. Concomitant administration of drugs at a fixed ratio 0.5:0.5 and 0.25:0.25 of their individual $\mathrm{ED}_{50}$ values reduced their $\mathrm{ED}_{50 \mathrm{~s}}$ to $2.3: 18.6 \mathrm{mg} / \mathrm{kg}$ and $2.2: 16.5 \mathrm{mg} / \mathrm{kg}$ separately. $\mathrm{ED}_{50 \mathrm{~s}}$ isobolographic analysis showed synergistic analgesic effects of both drugs. Additionally, coadministration of both drugs had effective analgesic and anti-inflammatory effect, as seen by formalin test, led to a significant rise in latency to lift right foot beside a significant decline in foot lifting frequency when compared with control value, the antiinflammatory reaction was demonstrated by a significant decrease in foot thickness compared to control value. In conclusion, the data indicate that diclofenac and silymarin coadministration controls acute pain synergistically, and suppress inflammatory reaction.
\end{abstract}

DOI: 10.33899/ijvs.2021.127065.1453, (C2021, College of Veterinary Medicine, University of Mosul.

This is an open access article under the CC BY 4.0 license (http://creativecommons.org/licenses/by/4.0/).

\section{Introduction}

In recent years, multimodal analgesia and antiinflammatory techniques have been suggested, combining additive and synergistic effects of multiple analgesics and anti-inflammatory effects with fewer adverse effects and offering more effective properties. Diclofenac sodium is a Non-Steroidal Anti-Inflammatory Drug (NSAID), with an average relative inhibition cyclooxygenase 1 and 2 (1). Diclofenac has serious pathological effects such as stomach ulceration, GIT bleeding, liver toxicity, kidney papillary necrosis as well as kidney failure on uses for long periods (2). Recently, use of natural compounds, including those extracted from vegetables, fruits, and herbs, as powerful preventive or therapeutic agents has become a promising approach for inflammation-associated disease chemoprevention (3).

Silymarin is a mixture of flavolignans resulting from ripe seed of medicinal herb Silybum marianum; containing primarily silybinin $\mathrm{A}$ and $\mathrm{B}$, isosilybinin, silychristin, silydianin, and taxifolin, the word silymarin generally includes dihydroflavonol taxifolin and flavolignans (silybinin, isosilybinin, and taxifolin), silymarin includes antioxidants, anti-inflammatory, antifibrotic, antiviral agents as well as immunomodulatory characteristics (4).

According to our research, no studies found to explain the analgesic efficacy and anti-inflammatory effect of diclofenac and silymarin coadministration in chicks model, 
for this reason, the object of our study to evaluate the analgesic and anti-inflammatory activity of diclofenac and silymarin in chicks.

\section{Materials and methods}

\section{Experimental animals}

One day-old chicks were bought from a licensed hatchery and kept until the tests were completed seven to nine days. Chicks were placed in a room at $32-35^{\circ} \mathrm{C}$, persistent illumination, lumber sawdust was used to cover the floor, Food and water were available all the time. All experiments complied with lab animal use regulations and sufficient care was given to the chicks.

The scientific board of the Department of Physiology, Biochemistry, and Pharmacology of the Veterinary Medicine College at the University of Mosul has appraised and accepted the protocol of study. The required doses of silymarin (175 mg, 21 ${ }^{\text {st }}$ Century HealthCare, Inc.) was dissolved in propylene glycol (Sigma chemical CO. 99\%).Diclofenac sodium $(75 \mathrm{mg} / 3 \mathrm{ml}$, Gulf Pharmaceutical Industries, UAE) was additional dilute in normal saline (Pharmaceutical Solution Industry, Saudi Arabia) to gain the wanted concentrations of drug.

The dosage of administration for each drug was intraperitoneally given at $5 \mathrm{ml} / \mathrm{kg}$ of body weight. At the same time, the experimenters observed the chicks' reactions during the tests that had been followed from 9-12 a.m.

\section{Experiments}

Up-and-down procedure (5) was used to determine the median effective doses of silymarin and diclofenac separately, or concomitantly (silymarin followed immediately by diclofenac) for induction analgesia in chicks.

Analgesia was assessed using an electric stimulator (Science and Research Instruments Ltd, UK) to increase the pain threshold after setting the frequency at $50 \mathrm{~Hz}$, width at $5 \mathrm{~ms}$ as well as pulse amplitude at 10 volts, the electrodes of stimulator were mildly placed under the wing in free feather of upper chest area which wetted by water.

The chick's reaction to pain after electric stimulation was manifested as calls distress and/or wing wiggling. Each chick had a lowest voltage triggered aversive pain reaction before administration diclofenac and silymarin alone or concomitantly, after $15 \mathrm{~min}$ from administration drugs for each chick, the rise or reduce in voltage causing pain response has been calculated (6).

Generally, within two second after electrical stimulation, the latency for positive analgesic reaction was apparent, dose choice constructed on preliminary experiments.

The initial dose of silymarin was at $100 \mathrm{mg} / \mathrm{kg}$, ip while diclofenac was at $12 \mathrm{mg} / \mathrm{kg}$, ip. After determination of $\mathrm{ED}_{50 \mathrm{~s}}$ to the silymarin and diclofenac, the combination experiment was done in a fixed ratio from the $\mathrm{ED}_{50 \mathrm{~s}}$. The initial dosages of silymarin and diclofenac were 40 and 5 $\mathrm{mg} / \mathrm{kg}$, ip, respectively (0.5:0.5 of their individual $\mathrm{ED}_{50}$ values), also the initial dosages of silymarin and diclofenac were 20 and $2.5 \mathrm{mg} / \mathrm{kg}$, ip, respectively (0.25:0.25 of their individual $\mathrm{ED}_{50}$ values).

In order to evaluate kind of interaction engaged in administration of silymarin and diclofenac concomitantly, $\mathrm{ED}_{50 \text { s }}$ of two drugs were applied to isobolographic analysis (7). For isobolographic analysis, a straight line was drawn among the analgesic isoeffective doses $\left(\mathrm{ED}_{50}\right)$ of silymarin and diclofenac provided to the chicks each alone or concomitantly. On $\mathrm{x}$ - as well as y-axes separately, $\mathrm{ED}_{50}$ points of silymarin and diclofenac provided alone are described, straight diagonal line shows the additivity line (zero interaction) at the ED50 values, and the position of concomitantly points on left (below) and right (above) sides of additive line shows synergistic as well as antagonistic interactions, separately.

The $\mathrm{da} / \mathrm{Da}+\mathrm{db} / \mathrm{Db}$ equation calculated the interaction index. Da and $\mathrm{Db}$, respectively, are the separate silymarin and diclofenac ED50s for analgesia induction, while $\mathrm{da}$ and $\mathrm{db}$ are their joined ED50s for analgesia induction. An index of interaction of 1 implies additivity (no interaction), < 1 synergism, and > 1 antagonism (8).

Thirty chicks were divided randomly into five groups of six members, and use another anti-inflammatory analgesic method. Chicks were initiated with pain and inflammatory reactions through injection $0.05 \mathrm{ml}$ of 0.1 percent aqueous formalin in right foot plantar (9), left foot plantar was injected as a control measure with a normal saline $(0.05$ $\mathrm{ml})$.

Fifteen minute previously formalin injection, the five chick's groups were intraperitoneally injected with (normal saline and propylene glycol) $5 \mathrm{ml} / \mathrm{kg}$ (control), silymarin $80 \mathrm{mg} / \mathrm{kg}$, diclofenac $10 \mathrm{mg} / \mathrm{kg}$, silymarin + diclofenac $40+5 \mathrm{mg} / \mathrm{kg}$ respectively, and silymarin + diclofenac $20+2.5 \mathrm{mg} / \mathrm{kg}$ respectively.

Directly once formalin injection, within 3 minutes the period to lift the right foot and the rate of lifting right foot in response to formalin injection were recorded. Supplementary, we evaluated anti-inflammatory result of silymarin and diclofenac alone or concomitantly through calculating foot thickness $(\mathrm{mm})$ with digital caliber (Electronics Lab, China) formerly and 1 hour subsequently formalin injection. Anti-inflammatory reaction was measured as following (percentage): Anti-inflammatory reaction $=[$ change in control group foot thickness - change in thickness of foot for treatment group / change in control group foot thickness $] \times 100$

\section{Statistical analysis}

Data are shown as mean + SEM. Statistical analysis was carried out using a one-way analysis of variance and then subjected to LSD test. $\mathrm{P}<0.05$ was deemed significant. 


\section{Results}

As calculated by the up-and-down procedure, the $\mathrm{ED}_{50}$ values for silymarin and diclofenac were 76.6 and $9.3 \mathrm{mg} /$ $\mathrm{kg}$ ip, separately for analgesic induction (Table 1) and (Table 2).

Table 1: Median effective doses $\left(\mathrm{ED}_{50}\right)$ of intraperitoneally administered silymarin for analgesic induction via the electrostimulator test in seven to nine day-old chicks

\begin{tabular}{lc}
\hline Variable & Result \\
\hline ED $_{50}(\mathrm{mg} / \mathrm{kg})$ & 76.6 \\
Dose range given $(\mathrm{mg} / \mathrm{kg})$ & $100-80=20$ \\
Dose initially taken $(\mathrm{mg} / \mathrm{kg})$ & 100 \\
Dose lastly taken $(\mathrm{mg} / \mathrm{kg})$ & 80 \\
Total of chicks used & $6($ xxoxoo) \\
Dose-increase or decrease $(\mathrm{mg} / \mathrm{kg})$ & $20 \mathrm{mg} / \mathrm{kg}$ \\
\hline
\end{tabular}

${ }^{\mathrm{a} X-p o s i t i v e ~ a n a l g e s i c ~ r e s p o n s e ; ~ O-n o ~ a n a l g e s i c ~ r e s p o n s e . ~}$

The up-and-down procedure calculated the $\mathrm{ED}_{50}(6)$.
Table 2: Median effective doses of intraperitoneally administered diclofenac for analgesic induction via the electrostimulator test in seven to nine day-old chicks

\begin{tabular}{lc}
\hline Variable & Result \\
\hline $\mathrm{ED}_{50}(\mathrm{mg} / \mathrm{kg})$ & 9.3 \\
Dose range given $(\mathrm{mg} / \mathrm{kg})$ & $12-10=2$ \\
Dose initially taken $(\mathrm{mg} / \mathrm{kg})$ & 12 \\
Dose lastly taken $(\mathrm{mg} / \mathrm{kg})$ & 10 \\
Total of chicks used & $6($ xxooxx) \\
Dose-increase or decrease $(\mathrm{mg} / \mathrm{kg})$ & $2 \mathrm{mg} / \mathrm{kg}$ \\
\hline
\end{tabular}

${ }^{a} \mathrm{X}$-positive analgesic response; O-no analgesic response. The up-and-down procedure calculated the $\mathrm{ED}_{50}$ (6).

The combined administration of silymarin and diclofenac at a fixed ratio 0.5:0.5 of their $\mathrm{ED}_{50}$ values led in $\mathrm{ED}_{50}$ values of 18.6 and $2.3 \mathrm{mg} / \mathrm{kg}$ ip, respectively for analgesic induction (Table 3). The combined administration of silymarin and diclofenac at a fixed ratio 0.25:0.25 of their $\mathrm{ED}_{50}$ values led in $\mathrm{ED}_{50}$ values of 16.5 and $2.2 \mathrm{mg} / \mathrm{kg}$ $i p$, respectively, for analgesia induction (Table 4).

Table 3: Median effective doses of silymarin and diclofenac inducing analgesia via the electro-stimulator test in chicks at a fixed ratio 0.5:0.5 of their individual $\mathrm{ED}_{50}$ values

\begin{tabular}{|c|c|c|}
\hline Variable & \multicolumn{2}{|c|}{ Silymarin with diclofenac } \\
\hline $\mathrm{ED}_{50}$ & $18.6 \mathrm{mg} / \mathrm{kg}$ & $2.3 \mathrm{mg} / \mathrm{kg}$ \\
\hline Dose range given $(\mathrm{mg} / \mathrm{kg})$ & $40-10=30 \mathrm{mg} / \mathrm{kg}$ & $5-1.25=3.75 \mathrm{mg} / \mathrm{kg}$ \\
\hline Initial dose & $40 \mathrm{mg} / \mathrm{kg}$ & $5 \mathrm{mg} / \mathrm{kg}$ \\
\hline Last dose & $10 \mathrm{mg} / \mathrm{kg}$ & $1.25 \mathrm{mg} / \mathrm{kg}$ \\
\hline Total of chicks used & & $6(\mathrm{xxoxxo})^{\mathrm{a}}$ \\
\hline Dose-increase or decrease (mg/kg) & $10 \mathrm{mg} / \mathrm{kg}$ & $1.25 \mathrm{mg} / \mathrm{kg}$ \\
\hline Y & & 0.68 \\
\hline
\end{tabular}

${ }^{a} \mathrm{X}$-positive analgesic response; $\mathrm{O}$-no analgesic response. The up-and-down procedure calculated the $\mathrm{ED}_{50}(6) . \mathrm{Y}=$ calculated interaction index

Table 4: Median effective doses of silymarin and diclofenac inducing analgesia via the electro-stimulator test in chicks at a fixed ratio $(0.25: 0.25)$ of their individual $\mathrm{ED}_{50}$ values

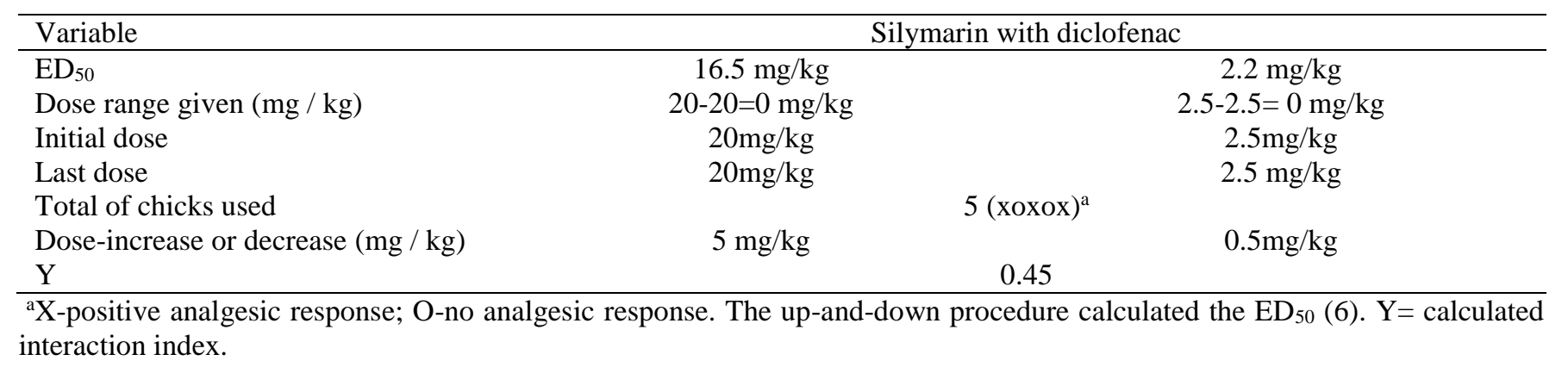

Isobolographic evaluation of these $\mathrm{ED}_{50 \text { s }}$ (alone or in combination) of both drugs at a fixed ratio either 0.5:0.5 or 0.25:0.25 revealed that the combined administration of drugs has a synergetic effect on analgesic induction in chicks (Figure 1 and 2) respectively. This synergistic effect was indicated by the position of the points below the diagonal line representing the combined analgesic $\mathrm{ED}_{50 \text { s }}$ of diclofenac and silymarin connecting their isoeffective 
analgesic doses $\left(\mathrm{ED}_{50 \mathrm{~s}}\right)$ given alone. Additionally, the interaction index calculated for analgesia at fixed ratio either $0.5: 0.5$ or $0.25: 0.25$ were 0.68 and 0.45 separately representing a synergistic interaction among both drugs (index $<1$ indicates synergism).

Usage of a unique anti-inflammatory and analgesic test, silymarin $80 \mathrm{mg} / \mathrm{kg}$ alone and diclofenac $10 \mathrm{mg} / \mathrm{kg}$ alone induced analgesia against pain induced by injected formalin into chick's foot planter region. This was demonstrated by a significant rise in latency to lift right foot as well as a significant decline in frequency of foot lift compared to the control value (Table 5). Combined silymarin and diclofenac show analgesic effect at 40 and $5 \mathrm{mg} / \mathrm{kg}$, and at 20 and 2.5 $\mathrm{mg} / \mathrm{kg}$ respectively. This was shown by a significant increase in latency to lift the right foot as well as a significant decrease in foot lift frequency relative to control value (Table 5). The anti-inflammatory activity of silymarin and diclofenac alone or in combination was demonstrated by a significant decrease of foot thickness relative to the control value. Silymarin $80 \mathrm{mg} / \mathrm{kg}$, diclofenac $10 \mathrm{mg} / \mathrm{kg}$, silymarin and diclofenac at 40 and $5 \mathrm{mg} / \mathrm{kg}$, as well as silymarin and diclofenac at 20 and $2.5 \mathrm{mg} / \mathrm{kg}$, showed an anti-inflammatory activity percentage of $21.8,51.2,44.8$, and 30.7 respectively compared to the control group (Table $6)$.

Usage of a unique anti-inflammatory and analgesic test, silymarin $80 \mathrm{mg} / \mathrm{kg}$ alone and diclofenac $10 \mathrm{mg} / \mathrm{kg}$ alone induced analgesia against pain induced by injected formalin into chick's foot planter region. This was demonstrated by a significant rise in latency to lift right foot as well as a significant decline in frequency of foot lift compared to the control value (Table 5). Combined silymarin and diclofenac show analgesic effect at 40 and $5 \mathrm{mg} / \mathrm{kg}$, and at 20 and 2.5 $\mathrm{mg} / \mathrm{kg}$ respectively. This was shown by a significant increase in latency to lift the right foot as well as a significant decrease in foot lift frequency relative to control value (Table 5). The anti-inflammatory activity of silymarin and diclofenac alone or in combination was demonstrated by a significant decrease of foot thickness relative to the control value. Silymarin $80 \mathrm{mg} / \mathrm{kg}$, diclofenac $10 \mathrm{mg} / \mathrm{kg}$, silymarin and diclofenac at 40 and $5 \mathrm{mg} / \mathrm{kg}$, as well as silymarin and diclofenac at 20 and $2.5 \mathrm{mg} / \mathrm{kg}$, showed an anti-inflammatory activity percentage of $21.8,51.2,44.8$, and 30.7 respectively compared to the control group (Table $6)$.

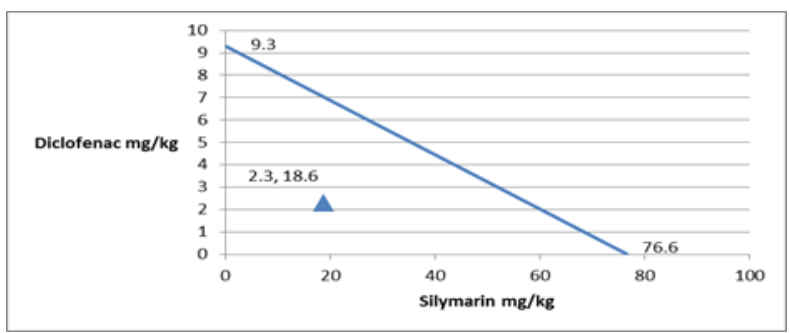

Figure 1: Isobolographic analysis of silymarin and diclofenac analgesic interactions in chicks. Intraperitoneally, silymarin and diclofenac were injected. Points on axes $\mathrm{x}$ and $\mathrm{y}$ are median analgesic doses $\left(\mathrm{ED}_{50 \mathrm{~s}}\right.$, $\mathrm{mg} / \mathrm{kg}$ ) of drugs administered alone, whereas the triangular point characterizes $0.5: 0.5$ of $\mathrm{ED}_{50}$ combinations of both drugs. The diagonal line between both the silymarin and diclofenac individual $\mathrm{ED}_{50 \mathrm{~s}}$ is synergistic, and thus the triangular point reveals synergistic relationship. $\mathrm{N}=5-6$ chicks / each experiment with an $\mathrm{ED}_{50}$.

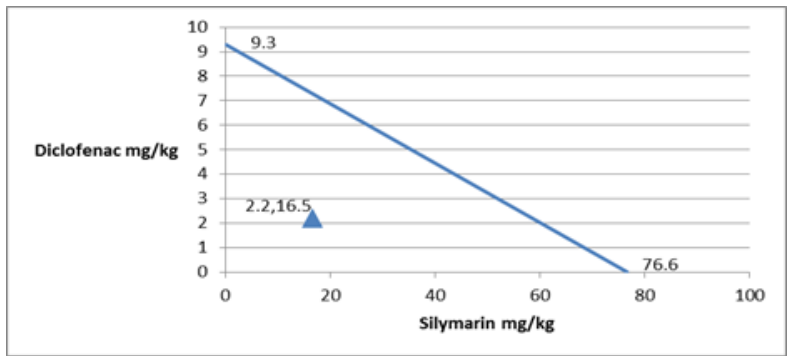

Figure 2: Isobolographic analysis of silymarin and diclofenac analgesic interactions in chicks. Intraperitoneally, silymarin and diclofenac were injected. Points on axes $\mathrm{x}$ and $\mathrm{y}$ are median analgesic doses $\left(\mathrm{ED}_{50 \mathrm{~s}}\right.$, $\mathrm{mg} / \mathrm{kg}$ ) of drugs administered alone, whereas the triangular point characterizes $0.25: 0.25$ of $\mathrm{ED}_{50}$ combinations of both drugs. The diagonal line between both the silymarin and diclofenac individual $\mathrm{ED}_{50 \text { s }}$ is synergistic, and thus the triangular point reveals synergistic relationship. $\mathrm{N}=5-6$ chicks / each experiment with an $\mathrm{ED}_{50}$.

Table 5: Onset of raising right foot and number of raising right foot in the chicks treated with silymarin and diclofenac alone or in combination

\begin{tabular}{lcc}
\hline Groups & Onset of raising right foot (second) & number of raising right foot (3min) \\
\hline Control & $0.86 \pm 0.05^{\mathrm{a}}$ & $45.67 \pm 2.52^{\mathrm{a}}$ \\
Silymarin $80 \mathrm{mg} / \mathrm{kg}$ & $1.08 \pm 0.08^{\mathrm{ab}}$ & $34.67 \pm 0.76^{\mathrm{b}}$ \\
Diclofenac $10 \mathrm{mg} / \mathrm{kg}$ & $1.41 \pm 0.20^{\mathrm{b}}$ & $21.83 \pm 1.44^{\mathrm{c}}$ \\
Silymarin $40 \mathrm{mg} / \mathrm{kg}+$ Diclofenac $5 \mathrm{mg} / \mathrm{kg}$ & $1.83 \pm 0.16^{\mathrm{c}}$ & $26.17 \pm 1.85^{\mathrm{c}}$ \\
Silymarin $20 \mathrm{mg} / \mathrm{kg}$ + Diclofenac $2.5 \mathrm{mg} / \mathrm{kg}$ & $1.00 \pm 0.00^{\mathrm{a}}$ & $26.83 \pm 1.99^{\mathrm{c}}$ \\
\hline
\end{tabular}

The values represent mean \pm SE for 6 chicks/group. Values of each column accompanied by various superscript letters are significantly different at significance level of 5 percent. 
Table 6: The increase in paw thickness and the anti-inflammatory activity $\%$ in the chicks treated with silymarin and diclofenac alone or in combination

\begin{tabular}{lcc}
\hline Groups & The increase in paw thickness $(\mathrm{mm})$ & The anti-inflammatory activity \% \\
\hline Control & $0.78 \pm 0.08^{\mathrm{a}}$ & 0 \\
Silymarin $80 \mathrm{mg} / \mathrm{kg}$ & $0.61 \pm 0.04^{\mathrm{b}}$ & 21.8 \\
Diclofenac $10 \mathrm{mg} / \mathrm{kg}$ & $0.38 \pm 0.03^{\mathrm{c}}$ & 51.2 \\
Silymarin $40 \mathrm{mg} / \mathrm{kg}+$ Diclofenac $5 \mathrm{mg} / \mathrm{kg}$ & $0.43 \pm 0.02^{\mathrm{c}}$ & 44.8 \\
Silymarin $20 \mathrm{mg} / \mathrm{kg}$ + Diclofenac $2.5 \mathrm{mg} / \mathrm{kg}$ & $0.54 \pm 0.02^{\mathrm{b}}$ & 30.7 \\
\hline
\end{tabular}

The values represent mean \pm SE for 6 chicks/group. Values of each column accompanied by various superscript letters are significantly different at significance level of 5 percent.

\section{Discussion}

In our study, we observed a synergistic relationship between diclofenac and silymarin coadministration in relieving pain (electro-stimulation test) and reducing pain and inflammation (formalin test) in chicks as a model. Chicks were used as a model for pain assessment, Holloway noted when comparing physiological responses of nociceptors in chickens with mammals, the discharge patterns, as well as receptive field size, are really comparable (10). For this reason, studying the analgesic action of pharmacological compounds in chickens can give an analogous picture of the act of analgesics in mammals.

Determination $\mathrm{ED}_{50}$ value is a sign of the drug's action in laboratory animals used in experiments as well as being of great importance in the determination of doses used in subsequent experiments. The current study explored the potential analgesic effect for silymarin in combination with diclofenac, while this effect has not been reported before. The analgesic impact of combined administration of silymarin and diclofenac was found to be synergistic as verified by isobolographic analysis of individual, as well as combined $\mathrm{ED}_{50 \mathrm{~s}}$ of both drugs for analgesia induction at a specified proportion $0.25: 0.25$ and $0.5: 0.5$ of their individual $\mathrm{ED}_{50 \mathrm{~s}}$, resulting in an interaction index of $<1$ 0.68 and 0.45 respectively.

Diclofenac is the most frequently used non-steroidal anti-inflammatory drugs in low, medium, and high-income countries, it is accessible over the counter in most countries, for a long time, non-steroidal anti-inflammatory drugs were used as effective anti-inflammatory therapeutic agents. However, they were often associated with severe side effects on long-term oral administration (11).

Diclofenac developed substantial analgesic effects in the chicks, either alone or in combination with silymarin (using an electric stimulator). Researchers have indicated multiple mechanisms of diclofenac in reducing acute pain. In mammals, the prolonged firing of $\mathrm{C}$-fiber nociceptors leads to glutamate release; it is presumed that is comparable in birds, glutamate then works in the spinal cord through $\mathrm{N}$ methyl-D-aspartate receptors lead to central sensitization, diclofenac reduces NMDA-mediated hyperalgesia in rats through L-arginine/NO/cGMP pathway (12). Another researcher pointed out that diclofenac's peripheral antinociceptive impact may result from the activation of several types of $\mathrm{K}+$ channels, which may cause hyperpolarized of peripheral terminals of primary afferents (13).

The experimental and clinical studies show the opioidrelated impact of diclofenac can be at least partly accountable for the analgesia observed after diclofenac administration; this effect can be one of the diclofenac analgesic mechanisms with the knowledge that birds have opioid receptors that are comparable to human receptors (14). Also, other molecular targets of diclofenac that contribute to its pain relief behavior, these includes: blockage voltage-dependent sodium channel and acidsensing ion channel, in addition to the main pharmacological action of NSAIDs ' analgesic are the consequence of their capacity to inhibit cyclooxygenase (COX) enzymes that catalyze the transformation of arachidonic acid into prostaglandins, which cause pain, increase temperature, and inflammation (15). All of these mechanisms may have a role in diclofenac pain relief.

Silymarin is a polyphenolic antioxidant flavonoid isolated from milk thistle fruits and seeds, Silybum marianum, Clinical acute toxicity studies showed that silymarin usually had exceptionally low toxicity and no side effects in certain dosage range on animals and humans (16). Malekinejad noticed that opioid receptors can mediate the antinociceptive effect of silymarin, also the antioxidant capacity of silymarin potentiates its antinociceptive properties (17). Another researcher pointed out silymarin's antinociceptive impact due to prostaglandin E2 inhibition (pain inducers), as well as silymarin has analgesic impacts through the histaminergic pattern (18).

The formalin test is used as an inflammatory tonic pain model. Pain has an inflammatory component. In our research, diclofenac has demonstrated important analgesic and anti-inflammatory effects in chicks, alone or in combination with silymarin (using the formalin test). Sensory fibers respond to physicochemical stimuli that produce mediators with both the source of tissues damage as well as inflammation, and these inflammatory mediators trigger or stimulate afferent nerves, transmitting neural impulses to the spinal cord via peripheral nerves and cranial 
nerves to cranial nerve ganglia (19). Inflammation, causally related to the release of pro-inflammatory cytokines such as interleukin-1 $\beta$ (IL-1 $\beta$ ), interleukin-6 (IL-6), tumor necrosis factor-alpha (TNF- $\alpha$ ), and cyclooxygenase-2 (COX-2) has been shown (20).

Prostaglandins are one of the most significant inflammatory pain mediators; COX enzymes induce prostaglandin during inflammation, prostaglandin E2 besides other cyclooxygenase products work synergistically with all other mediators to induce inflammatory nociception: while it has indirect pain-producing action, PGE2 sensitizes receptors in the endings of afferent nerve to bradykinin and histamine activities,cyclooxygenase occurs in most body tissues and can be regulated with a multitude of stimuli (21). The main impact of NSAIDs is to inhibit cyclooxygenase, thus interfering with the ultimate conversion of arachidonic acid into prostaglandins, prostacyclin, and thromboxanes (16).

The formation of inflammatory mediators is inhibited by silymarin, In particular, prostaglandins and leukotrienes (inhibiting 5-lipoxygenase pathway) and histamine release from basophils (22). Also, silymarin suppressed TNF- $\alpha$, blocked the IL-1 $\beta$ and cyclooxygenase- 2 mRNA expression (23). Silymarin inhibited leukocyte accumulation in the carrageenan-induced paw edema model in rats then considerably decreased the number of neutrophils migrated to the inflamed site (24). Our results are an agreement with other studies; silymarin inhibits the formalin- induced nociceptive behavior in mice and rats (25).

\section{Conclusion}

In conclusion, it is a great value in the treatment of pain when two types of agents are combined at doses lower than therapeutic doses. As mentioned in the introduction to the study that diclofenac has multiple side effects, especially in chronic use, and for this reason, it is very useful to reduce the dose of diclofenac to decrease these side effects.

\section{Acknowledgement}

The authors share their appreciation for the limitless cooperation of the University of Mosul, College of Veterinary Medicine.

\section{Conflict of interest}

The authors state no competing interests.

\section{References}

1. Van der Marel CD, Anderson BJ, Romsing J, Jacqz, Aigrain E, Tibboel D. Diclofenac and metabolite pharmacokinetics in children. Pediatr Anesth. 2004;14(6):443-451. DOI: 10.1111/j.14609592.2004.01232.x
2. Albadrany Y, Naser A. Coenzyme Q10 coadministration with diclofenac augmented impaired renal function in broiler chickens (Gallus gallus domesticus). Vet World. 2020;13(4):642-648. DOI: 10.14202/vetworld.2020.642-648

3. Hassan AA, Asim RA. Effect of vitamin C and acetylsalicylic acid supplementation on some hematological value, heat shock protein 70 concentration and growth hormone level in broiler exposed to heat stress. Iraqi J Vet Sci. 2020;34(2):357-363. DOI: 10.33899/ijvs.2019.125950.1195

4. Karimi G, Vahabzadeh M, Lari P, Rashedinia M, Moshiri M. "Silymarin", a promising pharmacological agent for treatment of diseases. Iran J Basic Med Sci. 2011;14(4):308-317. [available at]

5. Dixon WJ. Efficient analysis of experimental observations. Annu Rev Pharmacol Toxicol. 1980;20(1):441-462. DOI: 10.1146/annurev.pa.20.040180.002301

6. Naser AS, Amin YM. Analgesic effect of silymarin in chicks. Iraqi J Vet Sci. 2019;33(2):273-276. DOI: 10.33899/ijvs.2019.162906

7. Alabdaly YZ, Al-Hamdany EK, Abed ER. Toxic effects of butylated hydroxytoluene in rats. Iraqi J Vet Sci. 2021;35(1):121-128. DOI: 10.33899/ijvs.2020.126435.1322

8. Tallarida RJ. Statistical analysis of drug combinations for synergism. Pain. 1992;49 (1):93-97. DOI: 10.1016/0304-3959(92)90193-F

9. Sharma JN, Samud AM, Asmawi MZ. Comparison between plethysmometer and micrometer methods to measure acute paw oedema for screening anti-inflammatory activity in mice. Inflammopharmacol. 2004;12(1):89-94. DOI: $10.1163 / 1568560.04773121400$

10. Holloway JA, Trouth CO, Wright LE, Keyser GF. Cutaneous receptive field characteristics of primary afferents and dorsal horn cells in the avian (Gallus domesticus). Exp Neurol. 1980;68(3):477488. DOI: 10.1016/0014-4886(80)90102-8

11. Wust S, Tischner D, John M, Tuckermann JP, Menzfeld C, Hanisch UK. Therapeutic and adverse effects of a non-steroidal glucocorticoid receptor ligand in a mouse model of multiple sclerosis. PLoS One.2 009;4(12):e8202. DOI: 10.1371/journal.pone.0008202

12. Björkman R, Hallman KM, Hedner J, Hedner T, Henning $M$. Nonsteroidal anti-inflammatory drug modulation of behavioral responses to intrathecal N-methyl-D-aspartate, but not to substance $\mathrm{P}$ and amino-methyl-isoxazole-propionic acid in the rat. J Clin Pharmacol. 1996;36(12suppl):20S-26S. [available at]

13. Al-Abdaly YZ, Saeed MG, Al-Hashemi HM. Effect of methotrexate and aspirin interaction and its relationship to oxidative stress in rats. Iraqi J Vet Sci. 2021;35(1):151-156. DOI: 10.33899/ijvs.2020.126490.1335

14. Björkman R, Hedner J, Hedner T, Henning M. Central, naloxonereversible antinociception by diclofenac in the rat. Naunyn Schmiedebergs Arch Pharmacol. 1990;342 (2):171-6. DOI: 10.1007/BF00166960

15. Voilley N, de Weille J, Mamet J, Lazdunski M. Nonsteroid antiinflammatory drugs inhibit both the activity and the inflammationinduced expression of acid-sensing ion channels in nociceptors. $\mathrm{J}$ Neurosci. 2001;21(20):8026-8033. DOI: 10.1523/JNEUROSCI.21-2008026.2001

16. Rahman MM, Alam MB, Islam MA, Haque AKMA. Non-steroidal anti-inflammatory drugs-an overview. J Med. 2006;7 (1):20-31. DOI: 10.3329/jom.v7i1.1358

17. Doehmer J, Weiss G, McGregor GP, Appel K. Assessment of a dry extract from milk thistle (Silybum marianum) for interference with human liver cytochrome-P450 activities. Toxicol Vit. 2011;25(1):2127. DOI: $10.1016 /$ j.tiv.2010.09.001

18. Malekinejad H, Taheri-Broujerdi M, Moradi M, Tabatabaie S. Silymarin potentiates the antinociceptive effect of morphine in mice. Phyther Res. 2011;25(2):250-265. DOI: 10.1002/ptr.3251

19. Gholizade NM, Mojtahedin A, Seyedsharifi R. Pain-relieving effects of Silymarin and its interaction with histamine H1 receptors in Rats. J Fasa Univ Med Sci. 2017;7(2):265-274. [available at]

20. Miranda HF, Sierralta F, Pinardi G. Neostigmine interactions with non-steroidal anti-inflammatory drugs. $\mathrm{Br} \quad \mathrm{J}$ Pharmacol. 2002;135(7):1591-1597. DOI: 10.1038/sj.bjp.0704599 
21. Carlson NG, Wieggel WA, Chen J, Bacchi A, Rogers SW, Gahring LC. Inflammatory cytokines IL-1 $\alpha$, IL-1 $\beta$, IL-6, and TNF- $\alpha$ impart neuroprotection to an excitotoxin through distinct pathways. J Immunol. 1999;163(7):3963-3968. [available at]

22. Al-Allaf LK, Al-Ashoo HA. The effect of CO-Q10 on the testicular histological changes in rats induced by imatinib. Iraqi $\mathrm{J}$ Vet Sci. 2021;35(1):189-196. DOI: 10.33899/ijvs.2020.126587.1347

23. Ayoub SS, Botting RM, Joshi AN, Seed MP, Colville-Nash PR. Activation of macrophage peroxisome proliferator-activated receptor$\gamma$ by diclofenac results in the induction of cyclooxygenase- 2 protein and the synthesis of anti-inflammatory cytokines. Mol Cell Biochem. 2009;327 (1-2):101-110. DOI: 10.1007/s11010-009-0048-y

24. Santos ARS, Vedana EMA, De Freitas GAG. Antinociceptive effect of meloxicam, in neurogenic and inflammatory nociceptive models in mice. Inflammat Res. 1998;47(7):302-307. DOI: $10.1007 / \mathrm{s} 000110050333$

25. Hassani FV, Rezaee R, Sazegara H, Hashemzaei M, Shirani K, Karimi G. Effects of silymarin on neuropathic pain and formalin-induced nociception in mice. Iran J Basic Med Sci. 2015;18(7):715-720. [available at]

\section{دراسة التأثير المسكن المترافق للايكلوفيناك والسليمارين في أفراخ الاجاج}

ياسر محمدامين البدراني، احمد صلاح ناصر و محمد مرعي حسن

فرع الفسلجة والكيمياء الحياتية والأدوية، كلية الطب البيطري، جامعة الموصل، الموصل، العراق المباء

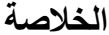

كان الهدف من الدراسة الكثف عن التأثير المسكن والمضاد

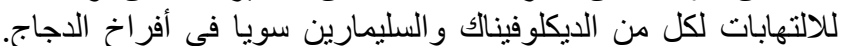

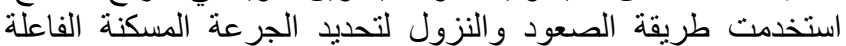

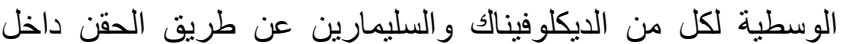

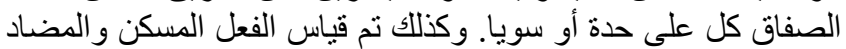

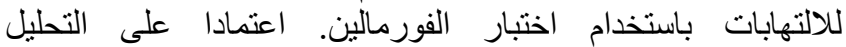

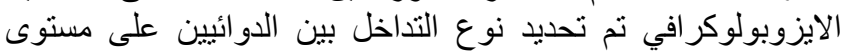

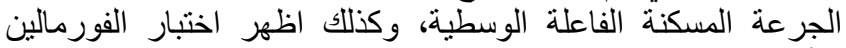

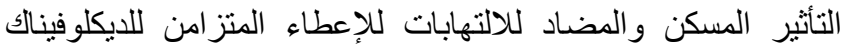

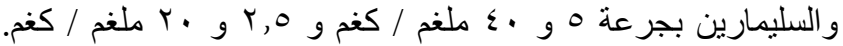
كانت الجرعة المسكنة الفاعلة الوسطية للايكلوفيناك ولاك و السليمارين في

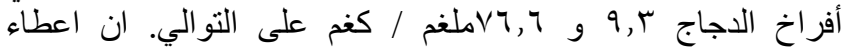

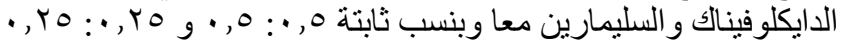

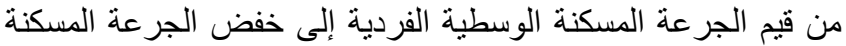

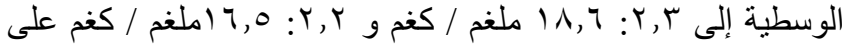

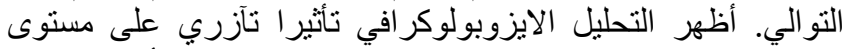

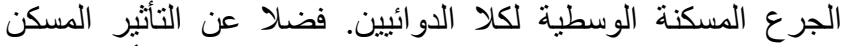

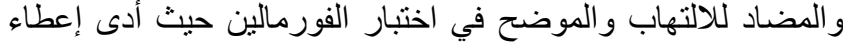

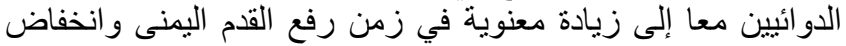

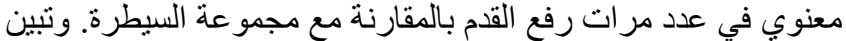

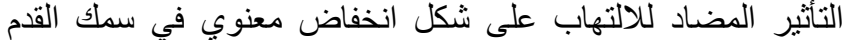

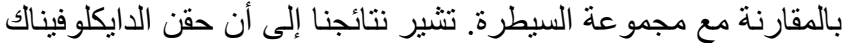

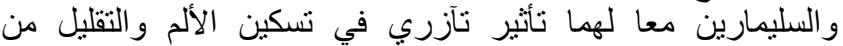

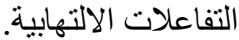

